\title{
Work capacity evaluation among nursing aides
}

\author{
AVALIAÇÃO DA CAPACIDADE PARA O TRABALHO ENTRE AUXILIARES DE \\ ENFERMAGEM
}

\author{
EVALUACIÓN DE LA CAPACIDAD PARA EL TRABAJO ENTRE AUXILIARES DE \\ ENFERMERÍA
}

Maria Silvia Monteiro ${ }^{1}$, Neusa Maria Costa Alexandre ${ }^{2}$, Daniela Milani ${ }^{3}$, Fernanda Fujimura ${ }^{4}$

\begin{abstract}
Work force aging generates the need to develop studied with the purpose to evaluate work capacity. The objective of this study was to analyze the work capacity of the nursing aides of a public health institute. A cross-sectional study was developed on the work capacity of these professionals regarding their demographic, work and lifestyle characteristics ( $n=241)$. A univariate logistic regression analysis was performed with inadequate work capacity (score below 37) as the dependent variable. There was an association with age (the eldest), work time at the institution (the oldest), body mass index (obesity) and item 1 of the work capacities index: present work capacity. This information can be used to create preventive measures and restore work capacity.
\end{abstract}

\section{DESCRIPTORS}

Nurses' aides

Work capacity evaluation

Cross-sectional studies

Occupational health

\section{RESUMO}

O envelhecimento da força de trabalho gera a necessidade de se desenvolver estudos a fim de avaliar a capacidade para o trabalho. O objetivo deste estudo foi analisar a capacidade para o trabalho de auxiliares de enfermagem de uma instituição pública de saúde. Foi desenvolvido um estudo transversal sobre capacidade para o trabalho desses profissionais em relação às características demográficas, de trabaIho e estilo de vida $(n=241)$. Uma análise de regressão logística univariada foi desenvolvida tendo a capacidade para o trabalho inadequada (menor que 37 pontos) como variável dependente. Foi encontrada associação em relação à idade (os mais velhos), ao tempo de trabalho na instituição (o mais antigo), o índice de massa corpórea (obesidade) e o item 1 do índice de capacidade para o trabalho: capacidade de trabalho atual. Essas informações podem ser utilizadas para medidas preventivas e para restaurar a capacidade para o trabalho.

\section{DESCRITORES}

Auxiliares de enfermagem

Avaliação da capacidade de trabalho

Estudos transversais

Saúde do trabalhador

\section{RESUMEN}

El envejecimiento de la fuerza laborar genera la necesidad de desarrollar estudios que evalúen la capacidad para el trabajo. Este estudio objetivó analizar la capacidad para el trabajo de auxiliares de enfermería de una institución pública de salud. Se desarrolló estudio transversal sobre capacidad para el trabajo de auxiliares de enfermería en relación a características demográficas, laborales y estilo de vida $(n=241)$. Fue efectuado un análisis de regresión logística univariada, teniendo la capacidad inadecuada para el trabajo (<37 puntos) como variable dependiente. Se encontró asociación relacionada a la edad (los mayores), al tiempo de trabajo en la institución (el más prolongado), al índice de masa corporal (obesidad); y el ítem del índice de capacidad para el trabajo, capacidad de trabajo actual. Estas informaciones pueden utilizarse para generar medidas preventivas y para restaurar capacidades laborales.

\section{DESCRIPTORES}

Auxiliares de enfermería Evaluación de capacidad de trabajo Estudios transversales Salud laboral

${ }^{1}$ Ph.D. in Public Health, Nurse. Associated Professor, Nursing Department, Federal University of São Carlos. São Carlos, SP, Brazil. silmont@ufscar.br ${ }^{2}$ Ph.D. in Nursing, Nurse. Associated Professor, Campinas State University. Campinas, SP, Brazil. neusalex@fcm.unicamp.br ${ }^{3}$ Nurse, Nursing Graduate Program, Scientific Initiation CNPq-PIBIC. Federal University of São Carlos. São Carlos, SP, Brazil. danmilani@bol.com.br ${ }^{4}$ Nurse, Nursing Department, Scientific Initiation, PUIC, Federal University of São Carlos. São Carlos, SP, Brazil. fernandafujimura@bol.com.br 


\section{INTRODUCTION}

The work conditions and risk factors for nursing workers' health have been studied in Brazil and abroad ${ }^{(1-5)}$. Special attention needs to be given to an aging work force. The nursing work force is aging, with significant social and cultural implications that also affect the workplace ${ }^{(6)}$. It is important to assess risks specific to the aging population, including diseases, physiological changes and psychosocial factors.

In the context of population aging, research has been developed to assess workers' work ability during the work life. The objective is to identify the factors that affect work ability and, based on this information, to plan and develop work ability promotion and preservation measures ${ }^{(7-8)}$.

The European Union developed a large study between 2002 and 2005, involving ten countries and a population of 38,000 nursing workers. It is called NEXT - Nurse's Early Exit Study ${ }^{(9)}$. In this study, the work ability was evaluated through the Work Ability Index (WAI), a methodology developed by Finnish researchers ${ }^{(10)}$.

In Brazil, studies concerning the evaluation of work ability have been developed among workers in several occupations ${ }^{(11)}$.

In the present study, an evaluation of nursing aides' work ability at a Brazilian public healthcare institution was developed.

\section{OBJECTIVE}

To evaluate the work ability of nurses' aides at a public health institution in relation to demographics, work and lifestyle characteristics.

\section{METHOD}

A cross-sectional study was developed. The data collection instrument included demographics, work and lifestyle variables. The work ability evaluation was done through the Work Ability Index ${ }^{(7,10)}$, developed by Finnish researchers and based on workers' self-perception. It is composed of seven items: current work ability compared with the lifetime best, work ability in relation to job demands, number of current diseases diagnosed by a physician, estimated work impairment due to diseases, sick leave during the past year (12 months), own prognosis of work ability two years from now and mental resources.
The final score varies from 7 to 49 points, distributed across the following categories: poor (7-27), moderate (28-36), good (37-43) and excellent work ability (44-49). In this study, data analysis was done using two categories: inadequate work ability (WAI<37) and adequate work ability (WAI $\geq 37$ ).

National and international recommendations concerning the ethical aspects of research with human beings were followed and approval for the research project was obtained from the Institutional Review Board at the Federal University of São Carlos, protocol number 42, 2001.

A large study covering all workers from a public healthcare institution ( $n=651$, response rate of $89.4 \%$ ) was developed. This paper presents the results concerning the most prevalent occupation, nurse's aides $(n=241)$. These workers had mixed work demands, that is, physical and mental work demands.

Univariate and multiple (WAI<37) logistic regression analyses were carried out with inadequate work ability as the dependent variable. The independent variables included in the analysis models and their characterization were identified during the descriptive analysis.

\section{RESULTS}

In total, 651 subjects participated in the study, with a mean age of 39.9 years. As expected, $83 \%$ of the subjects were women. With regard to work ability, 34 subjects had inadequate work ability (14.1\%).

There was no association between inadequate work ability and gender.

Table 1 shows the work ability of the nurse's aides related to demographics, work and lifestyle variables.

With regard to the age group, the groups from 45 to 54 years old and from 35 to 44 years were critical, because they showed a proportion of $44.1 \%$ and $35.3 \%$ of individuals with inadequate work ability.

Concerning marital status, $15.2 \%$ of the married subjects had inadequate work ability, similar to the proportion of subjects who lived alone (12.2\%).

The data indicated that $47.1 \%$ of the subjects with inadequate work ability had worked for more than 20 years.

Subjects who had another job corresponded to 73 (30.3\%) study participants, $20.6 \%$ of whom showed inadequate work ability. 
Table 1 - Work ability of nurse's aides and demographics, work and lifestyle characteristics

\begin{tabular}{|c|c|c|c|c|c|c|}
\hline \multirow{3}{*}{ Variable } & \multirow{3}{*}{ Category } & \multicolumn{4}{|c|}{ Work ability } & \multirow{3}{*}{ P Value } \\
\hline & & \multicolumn{2}{|c|}{ Inadequate } & \multicolumn{2}{|c|}{ Adequate } & \\
\hline & & $\mathbf{N}$ & $\%$ & $\mathbf{N}$ & $\%$ & \\
\hline \multirow[t]{3}{*}{ Gender } & Female & 28 & 82.3 & 172 & 83.1 & 0.9154 \\
\hline & Male & 6 & 17.7 & 35 & 16.9 & \\
\hline & Total & 34 & 100.0 & 207 & 100.0 & \\
\hline \multirow[t]{5}{*}{ Age group } & $20-34$ & 3 & 8.8 & 68 & 32.8 & 0.0116 \\
\hline & $35-44$ & 12 & 35.3 & 73 & 35.3 & \\
\hline & $45-54$ & 15 & 44.1 & 56 & 27.1 & \\
\hline & $55-69$ & 4 & 11.8 & 10 & 4.8 & \\
\hline & Total & 34 & 100.0 & 207 & 100.0 & \\
\hline \multirow[t]{5}{*}{ Education } & 4 years & 0 & 0 & 5 & 2.4 & $0.5378^{(1)}$ \\
\hline & 8 years & 10 & 29.4 & 39 & 18.8 & \\
\hline & 11 years & 23 & 67.7 & 151 & 73.0 & \\
\hline & Higher & 1 & 2.9 & 12 & 5.8 & \\
\hline & Total & 34 & 100.0 & 207 & 100.0 & \\
\hline \multirow{5}{*}{$\begin{array}{l}\text { Time of work at } \\
\text { institution }^{(2)}\end{array}$} & Until 1 & 1 & 2.9 & 58 & 28.0 & 0.0001 \\
\hline & 1 to 10 & 14 & 41.2 & 94 & 45.4 & \\
\hline & 11 to 20 & 3 & 8.8 & 21 & 10.2 & \\
\hline & 21 to 50 & 16 & 47.1 & 34 & 16.4 & \\
\hline & Total & 34 & 100.0 & 207 & 100.0 & \\
\hline \multirow[t]{3}{*}{ Having another job } & No & 27 & 79.4 & 141 & 68.1 & 0.1840 \\
\hline & Yes & 7 & 20.6 & 66 & 31.9 & \\
\hline & Total & 34 & 100.0 & 207 & 100.0 & \\
\hline \multirow[t]{3}{*}{ Smoking habits } & No & 17 & 50.0 & 123 & 59.4 & 0.3022 \\
\hline & Yes & 17 & 50.0 & 84 & 40.6 & \\
\hline & Total & 34 & 100.0 & 207 & 100.0 & \\
\hline \multirow[t]{4}{*}{ Body Mass Index ${ }^{(3)}$} & Normal & 18 & 54.6 & 118 & 57.6 & 0.0063 \\
\hline & Overweight & 7 & 21.2 & 72 & 35.1 & \\
\hline & Obesity & 8 & 24.2 & 15 & 7.3 & \\
\hline & Total & 33 & 100.0 & 205 & 100.0 & \\
\hline \multirow[t]{3}{*}{ Doing housework } & No & 2 & 5.9 & 21 & 10.1 & $0.7514^{(1)}$ \\
\hline & Yes & 32 & 94.1 & 186 & 89.9 & \\
\hline & Total & 34 & 100.0 & 207 & 100.0 & \\
\hline \multirow[t]{3}{*}{ Practicing physical exercise } & No & 18 & 52.9 & 92 & 44.4 & 0.3566 \\
\hline & Yes & 16 & 47.1 & 115 & 55.6 & \\
\hline & Total & 34 & 100.0 & 207 & 100.0 & \\
\hline
\end{tabular}

(1) Fisher; (2) in years; (3) There were 3 lost data. Body mass index: normal $\leq 24.8$, overweight $>24.8$ to $\leq 29.3$ and obesity $>29.3$.

The presence of smoking habits did not show any association with having inadequate work ability.

With regard to the Body Mass Index (BMI), 24.2\% of the subjects with obesity had inadequate work ability.

The accomplishment of housework in this study showed no association with having inadequate work ability. The same occurred in relation to the practice of physical exercise. The most frequent types of physical activity were walking, gymnastics and playing soccer and volleyball.

Among the subjects who did not practice leisure activities, $67.0 \%$ had inadequate work ability.

The analysis of the presence of inadequate work ability in relation to the work ability index items (Table 2) showed an association between work ability and the demands of the job, estimated work impairment due to diseases, sick leave during the past year (12 months), own prognosis of work ability two years from now and mental resources, which includes enjoying regular daily activities, being active and alert and being full of hope for the future. All associations with inadequate work ability occurred among subjects who scored in the worst categories for each item.

The age varied from 20 to 68 years. The mean age was 45.8 years among individuals with inadequate work ability and 39.1 among subjects with adequate work ability $(p<0.0001)$. At the age of 50 years, the mean work ability was 38.6.

In the univariate logistic regression analysis (Table 3), an association was identified between inadequate work ability and the following characteristics: age (older), age 
group ( $\geq 45$ years), time of work at the institution (longer), Body Mass Index (obesity) and current work ability (poor).

In the multiple logistic regression analysis, an association was found between the presence of inadequate work ability and longer time of work at institution (OR 1.065, Confidence interval $1.027 ; 1.104, \mathrm{p}$ value 0.0007 ) and the Body Mass Index - obesity (OR 3.032, Confidence interval $1.043 ; 8.817, \mathrm{p}$ value 0.0417$)$.

Table 2 - Work ability of nurse's aides and the work ability index items

\begin{tabular}{|c|c|c|c|c|c|c|}
\hline \multirow{3}{*}{ Variable } & \multirow{3}{*}{ Category } & \multicolumn{4}{|c|}{ Work ability } & \multirow{3}{*}{ P Value } \\
\hline & & \multicolumn{2}{|c|}{ Inadequate } & \multicolumn{2}{|c|}{ Adequate } & \\
\hline & & $\mathbf{N}$ & $\%$ & $\mathbf{N}$ & $\%$ & \\
\hline \multirow{5}{*}{$\begin{array}{l}\text { Work ability in } \\
\text { relation to physical demands }\end{array}$} & Rather poor/very poor & 6 & 17.6 & 2 & 1.0 & 0.0001 \\
\hline & Moderate & 16 & 47.1 & 23 & 11.1 & \\
\hline & Rather good & 12 & 35.3 & 118 & 57.0 & \\
\hline & Very good & 0 & - & 64 & 31.0 & \\
\hline & Total & 34 & 100.0 & 207 & 100.0 & \\
\hline \multirow{5}{*}{$\begin{array}{l}\text { Work ability in } \\
\text { relation to mental demands }\end{array}$} & Rather poor/very poor & 3 & 8.8 & 0 & - & $0.0001^{(1)}$ \\
\hline & Moderate & 10 & 29.4 & 9 & 4.4 & \\
\hline & Rather good & 20 & 58.8 & 151 & 72.9 & \\
\hline & Very good & 1 & 3.0 & 47 & 22.7 & \\
\hline & Total & 34 & 100.0 & 207 & 100.0 & \\
\hline \multirow{6}{*}{$\begin{array}{l}\text { Estimated work } \\
\text { impairment due to diseases }\end{array}$} & Only part-time work & 2 & 5.8 & 0 & - & \\
\hline & Often slow down work pace & 4 & 11.8 & 1 & 0.5 & \\
\hline & Sometimes slow down work pace & 17 & 50.0 & 25 & 12.1 & \\
\hline & The job cause some symptomss & 7 & 20.6 & 27 & 13.0 & \\
\hline & No hindrance/no diseases & 4 & 11.8 & 154 & 74.4 & \\
\hline & Total & 34 & 100.0 & 207 & 100.0 & \\
\hline \multirow{5}{*}{$\begin{array}{l}\text { Sick leave during } \\
\text { the past year }\end{array}$} & From 25 to 99 days & 7 & 20.6 & 6 & 2.9 & $0.0001^{(1)}$ \\
\hline & From 10 to 24 days & 2 & 5.9 & 6 & 2.9 & \\
\hline & Until 9 days & 7 & 20.6 & 30 & 14.5 & \\
\hline & None at all & 18 & 52.9 & 165 & 79.7 & \\
\hline & Total & 34 & 100.0 & 207 & 100.0 & \\
\hline \multirow{4}{*}{$\begin{array}{l}\text { Own prognosis of work } \\
\text { ability two years from now }\end{array}$} & Unlikely & 7 & 20.6 & 3 & 1.4 & $0.0001^{(1)}$ \\
\hline & Not certain & 13 & 38.2 & 8 & 3.9 & \\
\hline & Relatively certain & 14 & 41.2 & 196 & 94.7 & \\
\hline & Total & 34 & 100.0 & 207 & 100.0 & \\
\hline \multirow{5}{*}{$\begin{array}{l}\text { Ability to enjoy } \\
\text { your regular daily activities }\end{array}$} & Never/rather seldom & 1 & 2.9 & 2 & 1.0 & $0.0001^{(1)}$ \\
\hline & Sometimes & 10 & 29.4 & 11 & 5.3 & \\
\hline & Rather often & 14 & 41.2 & 77 & 37.2 & \\
\hline & Often & 9 & 26.5 & 117 & 56.5 & \\
\hline & Total & 34 & 100.0 & 207 & 100.0 & \\
\hline \multirow[t]{5}{*}{ Being active and alert } & Never/rather seldom & 1 & 2.9 & 0 & - & \\
\hline & Sometimes & 4 & 11.8 & 2 & 1.0 & \\
\hline & Rather often & 16 & 47.1 & 74 & 35.7 & \\
\hline & Always & 13 & 38.2 & 131 & 63.3 & \\
\hline & Total & 34 & 100.0 & 207 & 100.0 & \\
\hline \multirow{5}{*}{$\begin{array}{l}\text { Being full of hope for } \\
\text { the future }\end{array}$} & Never/rather seldom & 5 & 14.7 & 2 & 1.0 & 0.0001 \\
\hline & Sometimes & 8 & 23.5 & 19 & 9.2 & \\
\hline & Rather often & 10 & 29.4 & 70 & 33.8 & \\
\hline & Continuosly & 11 & 32.4 & 116 & 56.0 & \\
\hline & Total & 34 & 100.0 & 207 & 100.0 & \\
\hline
\end{tabular}

(1) Fisher www.ee.usp.br/reeusp/
The most prevalent diseases with referred diagnosis by a physician were: $19.5 \%$ of musculoskeletal diseases (sciatica), $18.7 \%$ of injury due to accident (back), $10.4 \%$ of digestive diseases (gastritis or duodenal irritation), 9.5\% of cardiovascular disease (hypertension) and $7.9 \%$ of slight mental disorder or problem (including slight depression, tension, anxiety and insomnia). 
Table 3 - Univariate logistic regression analysis of work ability and demographics, work and lifestyle characteristics and work ability index items

\begin{tabular}{lccc}
\hline Variable & p value & OR & CI 95\% \\
\hline Age & 0.0003 & 1.081 & $1037 ; 1.129$ \\
Age group $\geq 45$ years old & 0.0081 & 2.706 & $1.294 ; 5.657$ \\
Time of work at institution & 0.0001 & 1.070 & $1.034 ; 1.107$ \\
Obesity (BIM) & 0.0133 & 3.496 & $1.098 ; 9.420$ \\
Current work ability & $<0.0001$ & 0.406 & $0.285 ; 0577$ \\
\hline
\end{tabular}

\section{DISCUSSION}

The aim of this study was to identify demographics, lifestyle and work characteristic variables associated with work ability among nurses' aides at a public healthcare institution. Nursing personnel faces many occupational problems and the nursing work force is rapidly aging. Hence, it is very important to study the interaction between work ability and related factors.

Using univariate logistic regression analysis, the significantly associated factors were age, body mass index (obesity), longer duration of the work at institution and current work ability compared with the lifetime best.

A study ${ }^{(12)}$ about low back disorders in welders and nurses identified a relationship between smoking, no exercise, overweight and low back disorders.

A cross-sectional study with registered nurses from 10 European countries ${ }^{(9)}$ showed that scores on the Work Ability Index were significantly lower in older nurses ( $\geq 45$ years old).

In a prospective study of Italian nurses ${ }^{(13)}$, a relation was identified between age, low work ability and thoughts of quitting the job or actually leaving. Low work ability was a predictor of thinking of quitting the job among nurses younger than 45 years and a predictor of actual leaving among nurses older than 45 years old.

A survey that investigated work ability and its relationship with quality of life reported that the WAI score of Taiwanese nurses increased with age up to 45 and decreased significantly thereafter ${ }^{(14)}$.

A researcher ${ }^{(15)}$ analyzed the relationship between age and Work Ability Index items among 19 to 62-year-old female home care workers in Finland. Perceived work ability decreased at an early age. The first sig nificant turning point was observed after 40 years of age and the second steeper decrease occurred after the age of 55.

The present study also showed a decline in work ability due to aging among Brazilian nurse's aides. The mean age

\section{REFERENCES}

1. Moreno LC, Monteiro MS. Resgate da produção científica sobre riscos à saúde no trabalho em enfermagem na década de 90. Acta Paul Enferm. 2003;16(3):81-7. of the subjects with inadequate work ability was around 45 years old. At the age of 50 years old, the mean work ability in this study was 38.6 points. The Finnish reference values $^{(10)}$ at this age for nursing workers were 35 points for women and 37 points for men. Hence, mean work ability index scores at this age were similar in Brazil and Finland.

In a study contrasting low and high turnover hospitals in relation to structural and management characteristics $^{(16)}$, it was identified that the work ability index was rated as good in both, but that it was higher in low turnover hospitals, called magnet hospitals.

Researchers ${ }^{(17)}$ studied the effects of a worksite physical intervention regarding physical fitness, perceived health status and work ability of female service workers during periods of 1 and 5 years. They compared an intervention and a control group and identified that the work ability index declined around three times faster in the latter than in the intervention group during the 5-year period.

A study ${ }^{(18)}$ assessed the impact of an ergonomics intervention on low-back pain rates among nurses in England. They compared female nurses from two hospitals during periods of 18 and 28 months. One of the hospitals had an ergonomics intervention to minimize unassisted patient handling and high-risk nursing tasks. They identified that the change in risk factors was insufficient to produce a substantial reduction in back pain.

\section{CONCLUSION}

The evaluation of work ability permitted identifying the factors associated with inadequate work ability and workers with reduced work ability. This information may be used to adopt preventive measures and restore work ability.

It is important to develop and put in practice strategies to minimize these risks and promote health and safety. The challenge is to learn how to manage workplace issues associated with an aging workforce. 
3. Eriksen W. Work factors as predictors of persistent fatigue: a prospective study of nurses' aides. Occup Environ Med. 2006;63(6):428-34.

4. Friis K, Ekholm O, Hundrup YA, Obel EB, Grønbaek M. Influence of health, lifestyle, working conditions, and sociodemography on early retirement among nurses: the Danish Nurse Cohort Study. Scand J Public Health. 2007;35(1):23-30.

5. Silva RCG, Felli VEA. Um estudo comparativo sobre a identificação dos riscos ocupacionais por trabalhadores de enfermagem de duas Unidades Básicas de Saúde do município de São Paulo. Rev Esc Enferm USP. 2002;36(1):18-24.

6. Healy ML. Management strategies for aging work force. AAOHN J. 2001;49(11):8-10.

7. Ilmarinen J. Work ability: a comprehensive concept for occupational health research and prevention. Scand J Work Environ Health. 2009;35(1):1-5.

8. Tuomi K, Ilmarinen J, Seitsamo J, Huuhtanen P, Martikainen $\mathrm{R}$, Nygard $\mathrm{CH}$, et al. Summary of the Finnish research project (1981-1992): to promote the health end work ability of aging workers. Scand J Work Environ Health. 1997;23 Suppl 1:66-71.

9. Camerino D, Conway PM, Van der Heijden BIJM, Estryn-Behar $M$, Consonni D, Gould D, et al. Low-perceived work ability, ageing and intention to leave nursing: a comparison among 10 European countries. J Adv Nurs. 2006;56(5):542-52.

10. Tuomi K, Ilmarinen J, Jahkola A, Katajarinne L, Tulkki A. Índice de capacidade para o trabalho. $2^{a}$ ed. São Carlos: Ed.UFSCar; 2005.
11. Monteiro MS, IImarinen J, Corrêa Filho H. Work ability of the workers in different age groups of a public health institution in Brazil. Int J Occup Saf Ergon. 2006;12(4):417-27.

12. Vieira ER, Kumar S, Narayan Y. Smoking, no-exercise, overweight and low back disorder in welders and nurses. Int J Ind Ergon. 2008;38(1):143-9.

13. Camerino D, Conway PM, Van der Heijden BIJM, EstrynBehar M, Costa G, Hasselhorn HM. Age-dependent relationships between work ability, thinking of quitting the job, and actual leaving among Italian nurses: a longitudinal study. Int J Nurs Stud. 2008;45(11):1645-59.

14. Chiu MC, Wang MJ, Lu CW, Pan SM, Kumashiro M, Ilmarinen J. Evaluating work ability and quality of life for clinical nurses in Taiwan. Nurs Outlook. 2007;55(6):318-26.

15. Pohjonen T. Perceived work ability of home care workers in relation to individual and work-related factors in different age groups. Occup Med. 2001;51(3):209-17.

16. Stordeur S, D'Hoore W; NEXT Study Group. Organizational configuration of hospitals succeeding in attracting and retaining nurses. J Adv Nurs. 2007;57(1):45-58.

17. Pohjonen T, Ranta R. Effects of worksite physical exercise intervention on physical fitness, perceived health status, and work ability among home care workers: five-years follow-up. Prev Med. 2001;32(6):465-75.

18. Smedley J, Trevelyan F, Inskip H, Buckle P, Cooper C, Coggon D. Impact of ergonomic intervention on back pain among nurses. Scand J Work Environ Health. 2003;29(2):117-23. 